\title{
Agricultural Pollution: An Assessment of Synthetic Fertilizer Application in Sudano- Sahelian Zone of Nigeria
}

\author{
Yunusa Hassan and Nazmul Hussain* \\ Department of Geography, NIMS University, India
}

Submission: May 08, 2018; Published: October 11, 2018

"Corresponding author: Nazmul Hussain, Department of Geography, NIMS School of Humanities and Social Science, NIMS University, India, Email: nazmul10@gmail.com

\begin{abstract}
The current pace of intensive agricultural practices in arid and semi-arid regions of Nigeria is frightening due to the modern indiscriminate use of synthetic fertilizer. Being a permanent agricultural land of the country, the soil strength, and quality of the region is threatened, and agricultural supplement remain the only option. With scarcity and high cost of organic fertilizer, the farmers are left with the preferred choice of inorganic fertilizer (synthetically made). Farmers maximize their productions though intensively use of chemical fertilizers, which consequently leached and contaminates underground water reservoir. Moreover, this residue further runoff to nearby surface water bodies and eventually caused eutrophication. This present study assessed the farmer attitudes toward the intensive application of synthetic fertilizer in northern Nigeria. The prime aim is to provide sustainable method of fertilizer application, formulation of effective policies and promotion of cordial collaboration and monitoring of progresses made. The required data collected from secondary sources. Standard analytical method is adopted for the analysis. The study found that preferences of synthetic fertilizer is due to the farmer's urge of good return and maximize the profit. Thus, it will recommend that there is need for public enlighten about the adverse effects of chemical fertilizers in human life and the environment. There is need for collaboration between policymakers and government to publicize the value of sustainable development. The present work provides decision-makers, prospective study and Government with a diagnostic approach of the situation for necessary planning.
\end{abstract}

Keywords: Synthetic fertilizer; Sustainability; Pollution; Sudano-Sahelian; Nigeria

\section{Introduction}

This study entails about agricultural pollution and assesses the synthetic fertilizer application in Sudano-Sahelian zones of Nigeria. Nigeria is Africa's most populous nation with an estimate population of 140.0 million people according to 2006 census conducted by Nigerian Population Commission but increased to an estimate of 189.6 million people as of $1^{\text {st }}$ January 2017 (UN Department of Economics and Social Affairs: Population Division). The population is rapidly increasing due to high birth rate and low death rate. Fertilizer use and needs vary across Nigeria depending on agro ecological conditions, government policies, cropping systems and fertilizer responsiveness. Nigeria has one of the most promising agricultural potential which is yet to be realized. From the year 1960 to 2005, it cereal production per hectare has only grown by about 40 per cent. This is small in comparison with countries like India 'grown by about 150 per cent' and Pakistan 'grown by about 200 per cent' since they have similar level of productivity at the beginning of that period.

As regard to the rate at which the Nigerian population is increasing, the cropping system remained the most vital source of income to the millions of people besides providing food and shelter. The country has been long importing staples like rice, maize and cassava but in efforts to encourage local production had now placed ban rice importation [1]. With regards to this, the soil is the most vital component of human economic development through crop productions as reported by Usman (2013). Decline in soil fertility and quality are among the main factors that affects the agricultural activities beside erosion and desertification [2]. The decline in soil fertility and quality was largely affiliated to poor agricultural practices and insufficiency of other nutrient to support good growth and development. These threats necessitate fertilization as the most vital option available for farmers to maximize their crop productions, minimized and possibly reverse these dreadful environmental hazards.

The study encompasses the Sudan and Sahel Savanna region of northern Nigeria that lies within latitude $11^{\circ} \mathrm{N}$ and $14^{\circ} \mathrm{N}$. This region historically provided higher Fertilizer subsidies than their southern counterparts since during the colonial era when administrations provided support for fertilizer use due to the concerns poses by soil depletion and desertification, Mustapha (2003). The soil of this region has low fertility and buffering capacity, FFD, 2011-Smith et al. (1997). The use of synthetic fertilizers on continuous basis and in substantial quantities 


\section{Annals of Social Sciences \& Management studies}

has always been of much concern among experts and decision makers, Olaitan et al. (1984). Millet, sorghum, cowpea, groundnut and sesame are the major cereal crops grown in this region. Experts are familiar with the eventualities resulting from the use of this chemically made fertilizers and other agrochemical in conventional form of agriculture which destroyed the national settings of our environment and lead to many deadly diseases.

The present study aimed to give a snapshot of the situation regarding the synthetic fertilizer application within the study area and give a diagnostic view, recommends the formulation of effective policies, and promotion of cordial collaboration and monitoring of progresses through explaining the economic values and environmental benefits of organic fertilizer application.

However, the study area receives rainfall only seasonally with a very highly pronounced dry season. Farmers apply more fertilizer to accelerate growth of the plant in order to meet their net return and profits. There is an essential need for using fertilizer either organic or inorganic and also an obligatory need for adopting a sustainable method of application.

\section{Review of Related Literature}

This present study assessed the farmer attitudes toward the intensive application of synthetic fertilizer in the SudanoSahelian zone of Nigeria. Just as animals must have certain vital nutrients in their food for proper nutrition to promote excellent growth and good health, the plants also required certain mineral nutrients in the soil and air too. These Plants absorb most of these essential nutrients through their roots and foliage's. On the other side, many soils do not have sufficient nutrients to support good growth and development. In highlight of major an issue, the former UN Secretary Kofi Anan called for a strategy to bring food security to Africa pointing out that Green Revolution had triple food productivity in Asia. Such called and the likes led to the African Fertilizer Summit. This is the largest meetings in history to focus on Africa's food issues.

The "Fertilizer summit" took place in Abuja Nigeria, June 2006. In attendance are the African head of states, Ministers, Policymakers, NGO's and Leaders in the private sector. The prime aim of the summit is to "discourse the urgent negative trend in fertilizer use and food security in the continent". Nagy and Edun (2002) report that during the early 1970's, there are evidence of low fertilizer application in Nigeria despite effort from both the State and Federal Government to subsidies fertilizers, sometimes at rate as high as 95 per cent but by the year 2005, fertilizer consumption is 7 per cent $\mathrm{kg} / \mathrm{ha}$ of arable land which is visibly lower than the Indian rate of $121 \mathrm{~kg} / \mathrm{ha}$ and Pakistan's $184 \mathrm{~kg} / \mathrm{ha}$ as reported by World resources Institute [3].

In Nigeria, fertilizer subsidy accounted for 30 per cent of the Federal Ministry of Agriculture budget even though only 3 per cent of the total annual budget is allocated to Agriculture, Mogue et al. (2012). The Government established a program in 1999 known as "Federal Market Stabilization Program FMSP" that lasted until 2011, Shima (2013). This program has the responsibility of accepting state request of fertilizer based on demand projections of their respective states (both subsidized and unsubsidized). In view of this, it promotes greater access to synthetic fertilizers.

\section{Methodology}

The analysis in this paper is based on secondary data collected by the authors on the nineteen (19) states of Northern Nigeria been situated in Sudan and Sahel Savanna zones respectively. The study employed descriptive statistics using appropriate statistical analysis techniques. Comparisons are made against the obtained results with the goal set to achieve by the present study for proper validation.

\section{Study Area}

This study relied on Sudan and Sahel Savannah region of Nigeria where rainfall occurs only seasonally but often intensive when it does come. The region has rainfall period of 4-5 months annually (begins in May, peak around august and end October). The main two distinct agricultural lands in this region are the dry land and Fadama. The dry land is characterized by high sand particle, low organic matter and the soil is washed away easily by high rainfall, Mortmore (1989), whereas the Fadama is dominated by alluvial clay particles characterized by high water holding capacity, Kparmwamg et al. (1990).

The region is believed to have covered 75.9 per cent of the Nigerian landmass and about 57 per cent of this region is believed to be under Agricultural activities 'either under crop productions or pasture' [2]. It is estimated that more than 70 per cent of the population of the region depend on agricultural activities for their livelihood and sources of income (Nigeria, NBS 2008 and 2010), CIA (2009). The region comprises of nineteen different States in Nigeria. As of 2008, about six different states have functional synthetic fertilizer blending plants (Bauchi, Borno, Gombe, Kano, Katsina and Zamfara State) and another six have nonfunctional plants (Yobe, Kebbi, Nasarawa, Niger and Sokoto State).

Oluwale [4], reported that about 98 per cent of the farmers in the Sudan and Sahel Savanna region used synthetic fertilizer as supplement but it intensive application depend on farm size and socio-economic standard of the farmers. The smaller farms holders tend to apply more fertilizer than the larger farms. Moreover, it is reported that small scale farmers uses fertilizer more intensively than the large scale farmers within the study area. However it is evident across the region that the population of small scale farmers constitutes the majority among the existing farmers.

The soil of northern Nigeria is the most important area for the production of varieties of cereal crops, legumes, vegetables, tubers and so on [5]. Consequently this region more recently complained about decline in production, decrease in soil quality and fertility. These threats forces farmer's to seek for available options to supplement the declining nutrients. Many farmers still has a popular believe that organic fertilizer remained scarce and sometimes unavailable. And see the synthetically made fertilizer's 


\section{Annals of Social Sciences \& Management studies}

remain the only option since it is available, abundance and will always result to good agricultural return and also maximized relatively cheap. Farmer's believed that use of this supplement profit margin. (Table 1-3), (Figure 1).

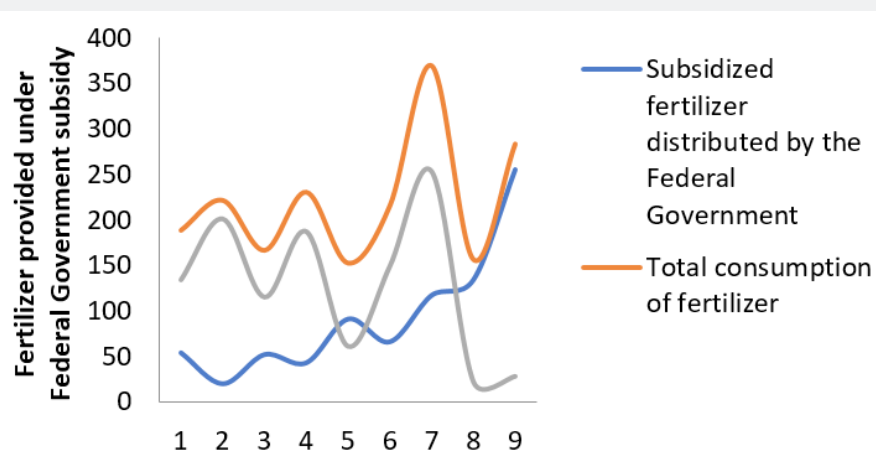

Figure 1: Fertilizer provided under Federal Government subsidy and Consumption of Commercial fertilizer in Nigeria from 2000 to 2008 (nutrients, 1000 ton).

Table 1: Fertilizer provided under Federal Government subsidy and Consumption of Commercial fertilizer in Nigeria from 2000 to 2008

(nutrients, 1000 ton)

\begin{tabular}{|c|c|c|c|}
\hline Year & $\begin{array}{c}\text { Subsidized Fertilizer } \\
\text { distributed by Federal } \\
\text { Government }\end{array}$ & $\begin{array}{c}\text { Total con- } \\
\text { sumption of } \\
\text { Fertilizer }\end{array}$ & $\begin{array}{c}\text { Commercial } \\
\text { Fertilizer }\end{array}$ \\
\hline 2000 & 54 & 188 & 134 \\
\hline 2001 & 20 & 221 & 201 \\
\hline 2002 & 52 & 166 & 115 \\
\hline 2003 & 43 & 230 & 187 \\
\hline 2004 & 91 & 152 & 61 \\
\hline 2005 & 66 & 215 & 149 \\
\hline 2006 & 117 & 369 & 253 \\
\hline 2007 & 134 & 156 & 22 \\
\hline 2008 & 255 & 283 & 28 \\
\hline
\end{tabular}

Sources: FAO (2012).

Table 2: Percentages of household by source of fertilizer obtained in the data.

\begin{tabular}{|c|c|c|c|}
\hline & $\mathbf{2 0 0 3}$ & $\mathbf{2 0 0 7}$ & $\mathbf{2 0 1 0}$ \\
\hline No fertilizer & $79.60 \%$ & $69.70 \%$ & $59.00 \%$ \\
\hline Use Fertilizer & $20.40 \%$ & $30.30 \%$ & $41 \%$ \\
\hline Uses commercial sources only: A & 88.9 & 82.6 & 82.7 \\
\hline Uses of subsidized sources only: B & 8.2 & 6.9 & 13.4 \\
\hline Uses both sources: A \& B & 2.8 & 10.5 & 3.9 \\
\hline
\end{tabular}

Source: Author's Calculation from Ephraim, (2014)

Table 3: Arithmetic mean of States subsidy rates in each geopolitical zone in 2008.

\begin{tabular}{|c|c|c|c|}
\hline \multirow{4}{*}{$\begin{array}{c}\text { Northern } \\
\text { Nigeria }\end{array}$} & $\begin{array}{c}\text { Geopolitical } \\
\text { zones }\end{array}$ & $\begin{array}{c}\text { Number of } \\
\text { states }\end{array}$ & $\begin{array}{c}\text { Average subsidy rate } \\
\text { (\%) }\end{array}$ \\
\cline { 2 - 4 } & North Central & 7 & 19.78 \\
\cline { 2 - 4 } & North West & 7 & 31.71 \\
\hline \multirow{3}{*}{$\begin{array}{c}\text { Southern } \\
\text { Nigeria }\end{array}$} & South East & 6 & 21.29 \\
\cline { 2 - 4 } & South South & 6 & 8.92 \\
\cline { 2 - 4 } & South West & 6 & 6.39 \\
\hline
\end{tabular}

Source: Author's Calculation from Banful et al. (2010, Table 1).
Table 4: Sources of local Organic Supplements.

\begin{tabular}{|c|c|c|}
\hline S/N & Organic Material & Local Name \\
\hline 1 & House refuse & Sharargida/Bola \\
\hline 2 & Poultry manure & Takingidangona \\
\hline 3 & Compost manure & Takingargajiya \\
\hline 4 & Cow dung & Kashinshanu \\
\hline 5 & Goat and sheep dung & Kashinawaki \\
\hline 6 & Donkey dung & Kashinjaki \\
\hline 7 & Rice husk & Dusanshinkafa \\
\hline 8 & Millet husk & Dusangero, etc. \\
\hline
\end{tabular}

Source: Usman, 2013

Based on the data in (Table 4), and chart A above, the use of synthetic fertilizer and their consumption is increasing, and it is evidently clear that farmers buy fertilizer from commercial sources with the aim of maximizing their crop productions. There is also relationship between fertilizer consumptions and unsubsidized fertilizer. These unsubsidized fertilizers are referred to commercial fertilizer in the table and chart above and are obtained from international market by private fertilizer manufacturers.

Note: The actual data from farmers if collected may differ from this one but this still provides useful insight. In contrast, this affects the farmer's decision in thinking that 'his agricultural return depends on the amount of fertilizer he applied' and forgetting the old traditional methods of agricultural practices. This imported irrigation and technological schemes which consequently favored farmer's decision in adoption of chemically made fertilizer.

The nutrient limitation is one of the prime constrain facing the agricultural productivities within this cereal dominated region [6], hence the cropping system remained the most important and vital source of income to the Millions of people in the rural area. For instance, during the year 2009 alone, about 45 per cent of the country's revenue was driven from agricultural sectors. There are highly pronounced effort by experts, government at both federal and states, Policy makers, other related bodies to maximized productivity through the use of supplements. 


\section{Fertilizer Application}

Fertilizers are any materials with natural or synthetic origin that are applied to the soil or the plant which supply essential nutrients for proper growth, development and production. This Fertilizer application strictly depends on the soil fertility, usually measured by soil test and in accordance to the particular crop planted. Historically, Nigerian states within the Sudano-Sahelian region have soil that has low buffering capacity and Government of this region has been providing greater fertilizer subsidies than their Southern counterpart. This region farmers tend to plant crops season after season and eventually cannot replace the nutrients taken by their crops, which vividly translate that the soil is literally mined of its life, Odhiambo (2006).

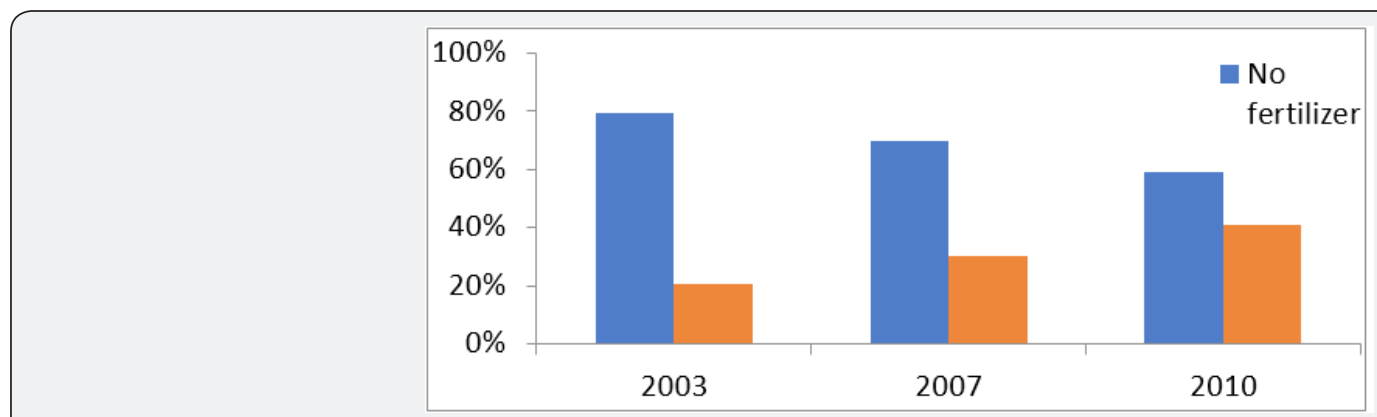

Figure 2: Percentages of household by source of fertilizer obtained in the data.

Over application of any chemically made fertilizer more than the recommended rate and on continuous basis tend creates a greater problem even though being a solution to the immediate food crisis for our consumer population. Farmers want to ensure good crop yield by using more than the recommended rates in order to maximize their agricultural profitability and apply so much such that it has a residual effect on the environment, flora and fauna. Furthermore, some amounts of excess fertilizer applied will leached and eventually pollute the underground water systems, Tankou (2004) (Table 2), (Figure 2).

It has been observed from 2003 to 2010, the fertilizer use more than doubled, despite the fertilizers from subsidized sources only accounted for 13.4 per cent of the total fertilizer used as of 2010. The farmers are willing to buy fertilizer in order to maximized production even if fertilizer from subsidies sources are little or not available at all. These translate that farmers have set their targets with the use of synthetically made fertilizers to maximized productions.

On contrary note, the intensification of inorganic fertilizer application in this region diminishes the value and economic benefits of local organic materials for the last 35 years, Usman et al. (2016) and in the same way Bationo et al. (2003) reported that sudden increased in soil acidity and decline of soil quality are as a result of unsustainable soil management in most of the state across Northern Nigeria. Singh et al. [6] report that moderate application of Nitrogen based fertilizers to increased net return and reduce the risk variability of weather and the price that comfort agricultural producer but synthetic fertilizers that are not taken up by plants during the growing season, plus that which is returned to the soil un-harvested portions accumulate in the soil assuming the losses due to erosion and leaching are small [7].

\section{Synthetic Fertilizer}

In spite Oluwale et al. [4] support and advocate the use of more Nitrogen based synthetic fertilizers in the Sub-Saharan Africa and more specifically the Sudano-Sahelian zone of Nigeria included.
He report that in within this region, the intensity of fertilizer application increases with family labor and physical access to fertilizer but on the other hand decreases with distance from the farmer's home. The fertilizer application has been identified as one of the source of nutrients supplement in the Savanna agroecological zone [8]. With the current intensity of agricultural production, soil is most often lack bioavailability phosphorus, Nitrogen and Potassium. Kitur et al. (1984) report that 28 to 42 per cent of synthetic fertilizer applied to maize remained in the soil. However, as noted by Sanchez and Black (1988), about 19 to 23 per cent of anhydrous ammonia applied to continuous maize cropping was still in the soil. The fertilizer rate been applied, rainfall pattern, leaching and runoffs are the main factors that affect the magnitude of the residual effects of synthetic fertilizer.

Since the fertility of the soil in this region constantly declining due to the poor agricultural practices and insufficiency of other nutrient that support good growth and development, Fertilizer remain the most vital option available for farmers to reverse this threat and maximized production. The intensive use of chemical fertilizer often lead to soil pollution with salt, infiltration of nitrous oxide to contaminate the underground water reservoirs, and runoff to nearby lakes, rivers, seas, and oceans to caused eutrophication. Furthermore, it has a catastrophic effect on living organism both the aquatic environment and those on the soil.

\section{Fertilizer Subsidy Regime in Nigeria}

The Federal Government of Nigeria has been procuring fertilizer for sale to State Government at subsidies rate of 25 per cent under the Market Stabilization program (FMSP) since 1999 (except in 2010), as reported by Afua et al. [9]. He further recommends that "average fertilizer subsidy rate within the country stand at 16.5 per cent, and both the highest amount of fertilizer procured and the highest subsidies giving by state are done by the Northern State Governments". The extension services in Northern Nigeria is highly stretched and only very small proportion of farmers can access them and most of the villages 
extension agent lack sufficient knowledge toward fertilizer and it applications rates. As a result of often corrupt practices by some individuals, most of the subsidies fertilizers are diverted by arbitragers, influential politicians and senior civil servants to the private fertilizer retailers. In the same way, Nagy and Odun (2002) estimated that it is only 30 per cent of the subsidies fertilizer that reaches a small farmer at that lower rate but still did not deterred farmers from intensively applying synthetic fertilizer because they at stick with the idea maximizing their profitability in order to sustain their lively hood (Table 3), (Figure 3).

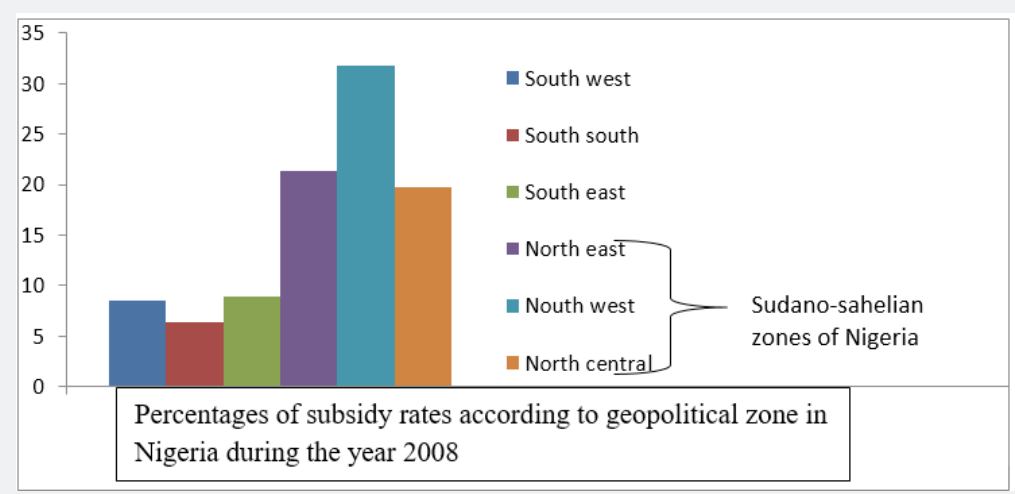

Figure 3: Arithmetic mean of States subsidy rates in each geopolitical zone in 2008.

With regards to the fertilizer subsidies provided by the federal government of Nigeria, the northern region (North Central, East and West) has always procured higher amount of fertilizer and also provide greater subsidies to the farmers of their region more than their southern counterparts.

\section{Organic Fertilizer}

Certainly, evidence shows that organic materials contain both macro and micro-nutrients that are more sustainable in crop productions that inorganic fertilizers as reported by FAO [10] and Uzoma et al. [11]. The Nigeria farming system is professed as a non-certified organic agricultural production, Bologun (2010). Both the farmers and the Nigeria Government are not interested in organic farming either they do not know the benefits or are not aware with the new trend of agriculture in the World. Notably Mgbenka et al. [12] report that in Nigeria, "certified Organic Farming is still in its infancy and there is need for it popularization and policy". There are limited if not non records of Government toward the advocating or encouragement of local farmers in production of more Organic agricultural products within the study area.

Mgbenka et al. [12] report that in one of most prolific research institute, the National Root Crops Research Institute NRCRI, Umudike, Abia State, Nigeria revealed that 'the Institute don't have any research work on organic farming and moreover they do not even have organic farming within their Curriculum'.

The main importance of organic fertilizer is seen through:

i. Enhanced nutrient availability

ii. Contribute to greater biodiversity

iii. Reduce dependant on inorganic fertilizer

iv. Contribute to proper waste management and it effective disposal

v. Lessen environmental pollution vi. Correction and maintaining the soil acidity and alkalinity

vii. Effectively increased yield and performance, etc.

These are some examples of locally generated organic materials used as fertilizer within the study area and their local name (Hausa Language) (Table 4). Most of the above listed waste materials are very common and can easily be found within the study area. Such materials can effectively be used as organic fertilizer without adding a single supplement will produce the desired result despite being environmentally friendly.

\section{Conclusion}

Generally, Environmentalist, Decision-makers and other Experts are already aware of the deadliest threat posed by the intensive application of inorganic fertilizer, there is an obligatory need for assessing the farmers attitude toward it usage, cross examination of the methods used in applying the fertilizer and also the amount applied during crop production and adopt a sustainable crop production system. A sustainable crop production system is a term used to describe a management philosophy that will be adopted by farmers who are going to remain as the future producers of human food, feed and fiber.

There have been efforts by the Governments both federal and state to toward providing inorganic fertilizer subsidies 'which runs into hundreds of millions' contributes toward affecting farmer's decisions to priorities the use of synthetic fertilizer more than organic fertilizer. The availability of this synthetic fertilizers from Government at subsidies rate certainly influences the farmer's decisions to intensively apply the synthetic fertilizer, with regards to believed that this region has history of Government intervention at both level within the study area in order to encourage massive agricultural productions that can meet off the growing population demand.

Regardless of this popular view that "an increased in inorganic fertilizer use is necessary for sustained productivity growth in sub 


\section{Annals of Social Sciences \& Management studies}

Saharan Africa", there is limited empirical evidence of how actual fertilizer use rates compare to economically profitable levels Lenis et al. (2014). Hence Chiano et al. (2004) argued that organic fertilizer application has potential to reverse the declining soil nutrient of the savanna region of Nigeria but due to ineffective adoption and usage by the farmers consequently which resulted to the declining in agricultural within this region. This practiced destroyed the national settings of the environment by altering the natural balance of the ecosystem and in many cases affect the quality of the food with the intake of mineral such as lead and excess copper which are known for been very deadly for human consumptions and eventually lead to deadly diseases [12].

In view of this, it is clear that researchers are well acquainted of the trend and eventualities resulting from the use of chemical fertilizers and other agrochemical in conventional form of agriculture. This paper agree with the view of Oluwale et al. [4] which reported that farmers with greater physical access to fertilizer, more labor, small land holding and cultivating crops especially those with high nutrient demand for example, cereal certainly tend to use more fertilizer intensively within the study area. In contrast, the private fertilizer sector in Nigeria is inexperienced and underdeveloped and could not fill the gap existing within the supply of organic fertilizer left by the Federal and State Governments in terms of supply. This issue led to the resumptions of fertilizer subsidies regime in 1999 by both Federal and State across the country.

The study further found that farmers and the village extension workers are the two major constrain of effective fertilizer application. In many cases, both the village extension worker and the farmer lack knowledge of technical knowhow to effectively use the synthetic fertilizer as argued by Donovan (2004), but this will curtailed through effective National Extension Services since extension workers if properly educated will enlighten the farmers on the problem associated with excessive usage of synthetic fertilizer and other related chemicals. In rain a fed agricultural system, fertilizer alone cannot guarantee high return without the complementary improved seeds [13]. This study strongly emphasis the need for vital readjustments to the traditional system of applying organic manure as a supplement in for more sustainability and economic growth. In regards to organic fertilizer as high alternative for sustainable crop production and maximum return, but to be more effective, farmers most take note of crop types, soil type, climatic conditions and management system into consideration. Waste and other materials used as organic fertilizer should be given utmost consideration since it may provide many economic opportunities to the growing population through jobs creation, poverty reduction programs, serve as effective waste management system, etc. [14-18].

In conclusion, cautious is required while using synthetic fertilizers, and it is never the absolute solution to the current food crisis of this region and the country in general. The study found that there are sharp increase in the use of synthetic fertilizer and identify that the intensity of the application will only result to more disastrous environmental problems since this nutrient will not be taking completely by the plants for their proper growth and development, residues must remained when a synthetic fertilizer is applied excessively in most cases [19-24].

\section{Recommendations}

Based on the findings of this study, the following recommendations were made:

i. Firstly, there is need for review of current agrochemical policies and programs, and more emphasis should be place on promotion of organic agriculture through adequate and prompt funding of researches and other related issues.

ii. Secondly, Federal, States and Local Governments within the study area should mount serious awareness campaigns to sensitize indigenous population on numerous benefits of organic farming through citing examples of dangerous treats posed by synthetic fertilizer on health, environment and the water resources promotion and development of local and regional market for organic products.

iii. Finally, both the private sector and non-Governmental organization NGO should get involved in the supporting measures for organic agro-business and campaigns. For instance, Creation of organic fertilizer plants, agricultural commodities modern storage facilities, Production and distribution of improve seeds, seedlings and brood stock, etc. in order to help farmers to maintain and maximize the profitability margins and returns.

iv. Further studies will be carried out on the level of heavy metals and other related pollutant in this region soil and water bodies (both underground and surface water bodies).

\section{References}

1. Anuforo E (2009) Nigerian's and \$3b yearly food import bill worries UK group, others. The Guardian, United Kingdom. Europe.

2. FMEN (2001) Federal Ministry of Environment of Nigeria. National action program to combat desertification. Federal Ministry of Environment, Abuja, Nigeria.

3. World Resources Institute (2010) Agriculture and food searchable database.

4. Olawale E0, Arega DA, Ikpi A (2009) Determinant of fertilizer Use in Northern Nigeria. Pakistan journal of social sciences 6(2): 91-98.

5. Usman S (2007) Sustainable Soil Management of the dry land soil of Northern Nigeria. GRIN Publishing GmbH, Munich, Germany.

6. Singh UJ, Diels J, Henao, H Breman (2001) Decision Support Systems for Improving the Application of Integrated Nutrient Management Technologies. In: Sustainability of Agricultural Systems in Transition. Crop Science Society of America and Soil Science Society of America, Madison, Wisconsin : 305-321.

7. Loks NA, Manggoel W, Daar JW, Mamzing D (2014) The Effects of Fertilizer Residues in Soils and Crop Performance in Northern Nigeria: A Review. Int Res Agric Sci Soil Sci 4(9): 180-184.

8. Manyong VM, Makinde KO, Ogungbile AGO (2002) Agricultural Transformation and Fertilizer use in the Cereal-Based Systems of the Northern Guinea Savanna, Nigeria. In: Integrated Plant Nutrient Management in Sub-Saharan Africa, Vanlauwe B, Diels J, Sanginga N, Merckx R (Eds.) CABI Publishing, New York: 75-85. 


\section{Annals of Social Sciences \& Management studies}

9. Afua BB, Ephraim N, Victor O (2010) Constraints of fertilizer use in Nigeria. Insight from Agricultural extension service. International food policy Research Institute (IFPRI Discussion paper 01010).

10. FAO (2005) Importance of Organic Matter: Key to drought resistant soil and sustained food production. FAO Soil Bulletin 80. Environment. Abuja, Nigeria.

11. Uzoma KC, Inone M, Andy H, Fujimaki H, Zahoor A, et al. (2011) Effects of Cow Manure on Maize productivity under Sandy soil condition. Soil use manage 27: 205-212.

12. Mgbenka RN, Onwubuya EA, Ezeano CI (2015) Organic farming in Nigeria: Need for Popularization and Policy. World Journal of Agricultural Sciences 11(6): 346-355.

13. Pender J, Nkonya E, Rosegrant M (2004) Soil fertility and fertilizer subsidies in Sub-Saharan Africa: Issues and recommendation. Power point presentation. International food and policy Research Institute: Washington, DC, USA.

14. Adesina AA, Zinnah MM (1993) Technology characteristics, farmer's perceptions and decisions: A Tobit model application in Sierra Leone. Agricultural Economics 9: 297-311

15. Ajeigbe HA, Mohammed SG, Adeosun JO, Ihedioha D (2010) Farmers Guide to Increase Productivity of Improved Legume-cereal Cropping System in the Savannas of Nigeria. IITA: Nigeria.

This work is licensed under Creative

Commons Attribution 4.0 License

DOI: 10.19080/ASM.2018.02555579
16. Banful A, Olayide O (2010) Perspectives of Selected Stakeholder Groups in Nigeria on the Federal and State Fertilizer Subsidy Programs. IFPRI NSSP Report 2008.

17. CIA (Central Intelligence Agency) (2016) The World factbook.

18. Elzbieta B (2011) Environmental Management in Practice. JanezaTrdine 9, 51000 Rijeka, InTech: Croatia, Europe.

19. Ephraim Nkonya, Hiroyuki Takeshima (2014) Government fertilizer subsidy and commercial sector fertilizer demand: Evidence from Federal Market Stabilization Program (FMSP) in Nigeria. International Food Policy Research Institute, USA.

20. FAO (2012) FAOSTAT 2012. Rome, Italy

21. Noel C, David D, Diana L, Bruce R (2009) A Companion to Environmental Geography, Blackwell Publishing Ltd, Hong kong.

22. Usman S (2003) Understanding Soil: Environmental and properties under agricultural activities. Publish Amera, LLLP, Baltimore, USA.

23. Hassan Y (2010) Assessment of Municipal Solid Waste Management in Potiskum Metropolis, Yobe State. Master's Dissertation (Unpublished). Bayero University Kano, Nigeria.

24. Ehigiator JO, Ariyo AD, Imasuen EE (2015) Soil fertility and nutritional studies on citrus, fruit and vegetable crops in Nigeria (1975 to 2005). Njafe 11(2): 103-114

\begin{tabular}{l} 
Your next submission with Juniper Publishers \\
will reach you the below assets \\
- Quality Editorial service \\
- Swift Peer Review \\
- Reprints availability \\
- E-prints Service \\
- Manuscript Podcast for convenient understanding \\
- Global attainment for your research \\
- Manuscript accessibility in different formats \\
( Pdf, E-pub, Full Text, Audio) \\
- Unceasing customer service \\
Track the below URL for one-step submission \\
https://juniperpublishers.com/online-submission.php \\
\hline
\end{tabular}

